\title{
РЕФОРМУВАННЯ ПОРЯДКУ ПРОВЕДЕННЯ КОНКУРСУ 3 ПЕРЕВЕЗЕННЯ ПАСАЖИРІВ НА АВТОБУСНОМУ МАРШРУТІ ЗАГАЛЬНОГО КОРИСТУВАННЯ
}

\author{
к.ю.н. Ларченко М. О., \\ доиент кафедри політології, права та філософії \\ Ніжинського державного університету імені Миколи Гоголя, Украйна, м. Ніжин
}

DOI: https://doi.org/10.31435/rsglobal_ejits/31072019/6579

\section{ARTICLE INFO}

Received 11 May 2019

Accepted 10 July 2019

Published 31 July 2019

\section{KEYWORDS}

passenger transportation, competition,

start rating of the carrier, dynamic carrier rating, route, terms of the contract of carriage.

\begin{abstract}
The article outlines the main provisions of the new concept of organization of passenger transport. The changes necessary for its implementation are proposed in the legal and regulatory framework. In particular, within the framework of the concept we are proposed: 1) the payment of the use of city infrastructure for carriers, determining the parameters and conditions that the city should provide for these funds; 2) the individualization of the business of transportation, the transition from hired labor to individual entrepreneurship; 3 ) organization of routes and schedules of traffic on applications of carriers; 4) rating of carriers according to open parameters, starting and dynamic ratings; 5) liability insurance of the carrier to the passengers for the fulfillment of the terms of the contract for the carriage, the responsibility of the vehicle owner to the carrier for the technical serviceability of vehicles, the responsibility of the carrier to the owner (manager) of the vehicle in accordance with the conditions of operation of the vehicle; 6) motivation of carriers for self-control using advanced technical means; 7) motivating carriers to provide additional services to the city (for example, monitoring the state of the carriageway, mobile video surveillance for security structures, etc.).
\end{abstract}

Citation: Ларченко М. О. (2019) Reformuvannia Poriadku Provedennia Konkursu z Perevezennia Pasazhyriv na Avtobusnomu Marshruti Zahalnoho Korystuvannia. European Journal of Intelligent Transportation Systems. 1(2). doi: 10.31435/rsglobal_ejits/31072019/6579.

Copyright: (C) 2019 Ларченко М. О. This is an open-access article distributed under the terms of the Creative Commons Attribution License (CC BY). The use, distribution or reproduction in other forums is permitted, provided the original author(s) or licensor are credited and that the original publication in this journal is cited, in accordance with accepted academic practice. No use, distribution or reproduction is permitted which does not comply with these terms.

Вступ. Як відомо, в країнах англо-саксонської та романо-германської правових систем розвиток міст йшов двома основними шляхами, які можна умовно назвати європейським i американським. Основа європейського міста - burge - міський податок (звідси “буржуазія" - ті, хто може сплатити міський податок). У сучасному європейському місті його роль виконують податки на нерухомість та землю. За сплачений burge містянин отримував певні соціальні та політичні права: право на незалежність від феодалів, право на поліцейський захист, право на використання інфраструктури міста і т.п. Транспортне обслуговування в “європейському” місті так само історично сформувалось для “буржуа", тобто замовником послуг виступає місто в особі його уповноваженого органу, а містяни користуються послугами, сплачуючи за них місту (80\% у вигляді податків та 20\% у вигляді провізної плати).

“Американське” місто формувалось на принципі: “дотримуйся правил і сплачуй лише за спожите", тобто мерія лише формулює “правила гри” для тих, хто надає послуги, а вже містяни самі вирішують, які послуги їм використовувати та оплачувати.

Зовсім інший принцип застосовується у місті, що розвивається за так званим радянським зразком. Нажаль, більшість українських міст залишається саме на цьому шляху, який показав свою повну неефективність і нежиттєздатність та зберігається швидше по інерції. 
Таким чином, в сучасних українських реаліях демократично обраному керівництву окремого міста необхідно вирішити, яким шляхом буде розвиватись його транспортна інфраструктура: підвищувати податки до європейського рівня (а чи багатьом містянам вони по кишені?) та брати всю відповідальність за функціонування інфраструктури (у тому числі і транспортної) на себе або сформувати "правила гри" та відпустити інфраструктуру у вільний ринок. Функціонувати за радянським зразком, поєднуючи низькі податки, низькі тарифи на перевезення, високі видатки на оновлення та ремонт автопарку навряд чи якесь місто може зараз собі дозволити.

Основними рисами описуваних систем є наступні.

1) європейської:

- замовником перевезень виступає місто,

- маршрутна мережа визначається та затверджується групою чиновників,

- підрядником перевезень виступають, як правило, муніципальні та комунальні підприємства,

- транспортні засоби знаходяться в комунальній власності,

- безпосередній виконавець перевезень найнятий підприємством за трудовим договором,

- інфраструктура забезпечення знаходиться в комунальній власності,

- контроль за роботою та їі оцінку / оплату здійснює група чиновників,

- підтримання інфраструктури відбувається за рахунок міського бюджету;

2) американської:

- замовником перевезень виступає пасажир,

- виконавцем перевезень $є$ приватна компанія (за винятком метрополітенів),

- транспортні засоби знаходяться у власності перевізника,

- маршрутна мережа визначається перевізниками за погодженням з муніципалітетом,

- безпосередній виконавець перевезень $\epsilon$ самозайнятим або найнятий приватним підприємством за трудовим договором,

- інфраструктура забезпечення (зупиночні пункти, технічні служби і т.п.) знаходяться у приватній власності. Перевізник платить за використання інфраструктури,

- контроль за роботою та її оцінку / оплату здійснює пасажир,

- муніципалітет визначає правила надання послуг та $€$ первісним арбітром у спірних ситуаціях;

3) американської модернізованої (турецької, ізраїльської...):

- виконавцем перевезень $\epsilon$ кооператив безпосередніх перевізників,

- транспортні засоби знаходяться в приватній або кооперативній власності,

- безпосередній виконавець є самозайнятим,

- решта аспектів ідентичні з наявними в американській системі.

Ряд дослідників опублікували свої результати концептуальних розробок у сфері організації транспортних перевезень. Зокрема, корисною є праця Зак Ю.А. Прикладные задачи теории расписаний и маршрутизации перевозок [3]. Автор наводить численні математичні моделі та методи розв'язання проблем транспортних перевезень, його висновки можуть бути корисними для реформування цієї галузі в Україні. Вагомий внесок у цю сферу досліджень в Україні зробили: Вакарчук I.М., Григор'єв Г.С., Гюлев Н.У., Доля В.К., І Ігнатенко О.С., Марунич В.С., Ткаченко А.М., Харута В.С., Шаповалова О.Л., Шморгун Л.Г., Шпильовий І.Ф. 3 останніх українських досліджень у цій сфері виділяється: підручник “Організація та управління пасажирськими перевезеннями” (2017) [4]. Робота є якісним аналізом дослідницької думки, що розвивалась не лише в Україні, а й далеко за кордоном.

Результати дослідження. На нашу думку, для українських міст найбільше підходить саме американська або американська модернізована система організації транспортної інфраструктури. Єдиною перепоною на цьому шляху $є$ наявність корупційної складової, яку якнайшвидше необхідно усунути для побудови системи за приватнопідприємницьким принципом.

Для реалізації цієї мети, у свою чергу, необхідно прийняти до уваги принципово нову транспортну концепцію.

Концепція змін у системі організації міського пасажирського транспорту, пропонована нами для впровадження в Україні, передбачає:

- підвищення комфорту, безпеки та якості перевезень;

- демонополізацію ринку;

- мінімізацію людського фактору при визначенні переможців конкурсу 3 перевезення пасажирів на автобусному маршруті загального користування;

- автоматизацію системи контролю та впливу на поточний стан перевезень. 
Зокрема, схематично проведення конкурсу з перевезення пасажирів на автобусному маршруті загального користування виглядає наступним чином.

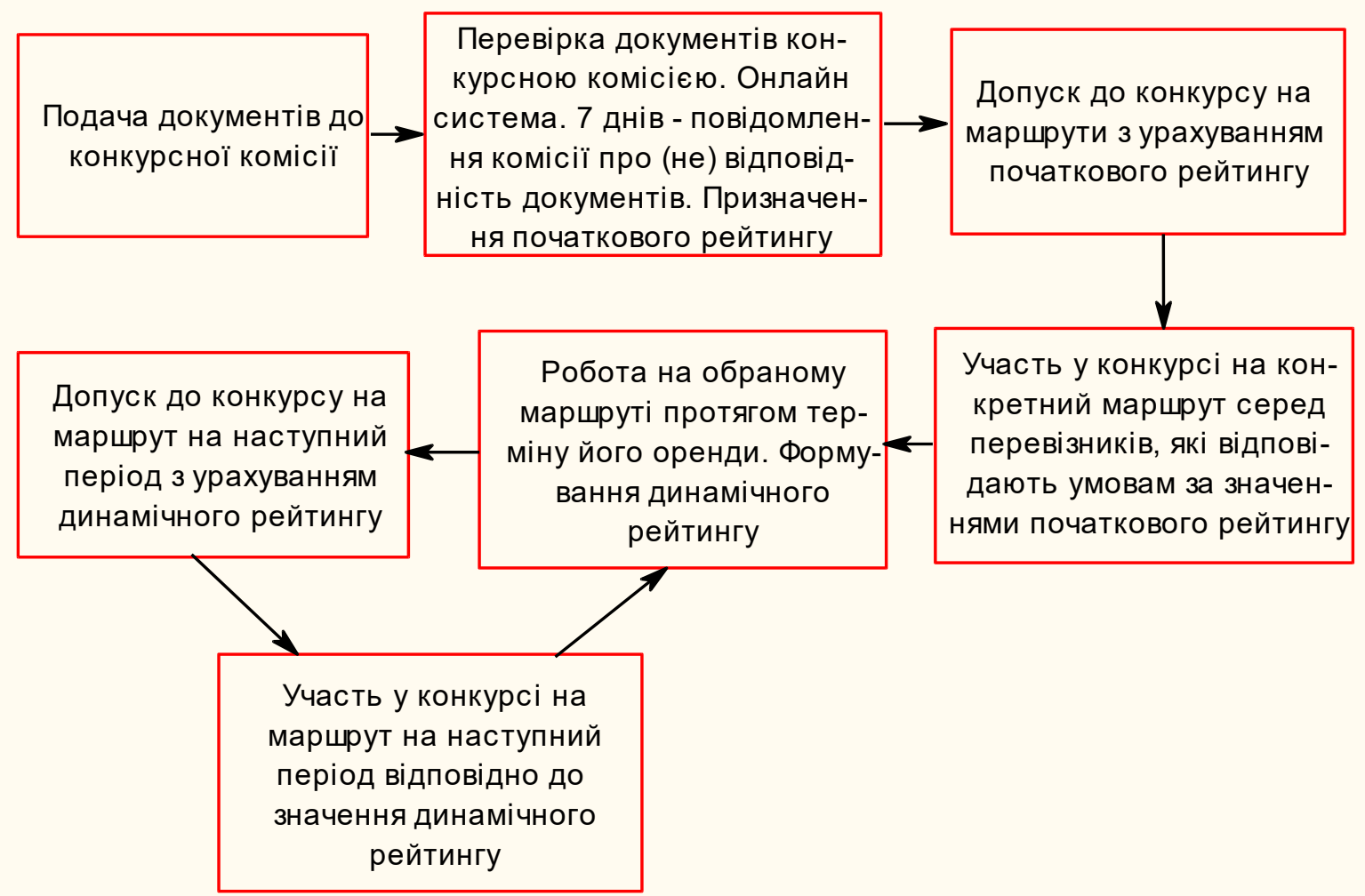

Рис. 1. Схема проведення конкурсу

Для впровадження описуваних змін у системі організації міського пасажирського транспорту (далі - Концепція) необхідним $є$ внесення відповідних змін до підзаконних актів, зокрема до Постанови Кабінету Міністрів України № 1081 https://zakon.rada.gov.ua/laws/show/10812008-\%D0\%BF .

Так в Україні Порядок проведення конкурсу з перевезення пасажирів на автобусному маршруті загального користування, затверджений Постановою КМУ № 1081 (далі - Порядок), поставив з 2008 року дрібних перевізників в Україні у вкрай невигідні умови у зв'язку з введенням системи бальної оцінки пропозицій перевізників-претендентів та встановленням мінімального строку укладення договору на пасажирські перевезення.

На практиці має місце ситуація, коли конкурс на найбільш прибуткових маршрутах виграє крупний перевізник за рахунок більшої кількості транспортних засобів у його розпорядженні. Власники декількох автобусів, не маючи можливості конкурувати в конкурсі, змушені здавати свої транспортні засоби переможцю конкурсу в оренду (саме так юридично оформлюються ці відносини). В реальності ж транспортні засоби ставляться на маршрут за щоденний "збір" в кишеню господаря компанії-переможця конкурсу на маршруті. Цей "збір" має довільну природу та не обкладається ніякими податками. Таким чином відбувається монополізація ринку пасажирських перевезень та приховування доходів.

Крім цього, корупційна складова завжди присутня і на етапі проведення конкурсу. Члени конкурсної комісії, які згідно Порядку включаються туди від імені громадських організацій (50\%), завжди є спеціально підібраними та “прикормленими" особами, бо не демократичною і не прозорою $є$ сама процедура їх відбору для включення до конкурсного комітету (п. 24 Порядку).

Що стосується водіїв транспортних засобів, то більша частина 3 них працює без оформлення, бо законодавець не створює умов, за яких це було б вигідно перевізникам. Конкурсний комітет заплющує на це очі, що представляє собою ще один корупційний момент.

Режим роботи водіїв прямо порушує відповідні норми Кодексу законів про працю. Велика кількість годин, що їх перепрацьовує водій, має наслідком значну кількість ДТП з вини 
водіїв автобусів (відповідна статистика тут www.sai.gov.ua/ua//ua/statis/21.htm), а також жодним чином не сприяє ввічливості водіїв з пасажирами.

Слід також сказати про такі, що довільно встановлюються, ціни на перевезення пасажирів. Це знову ж таки відбувається через монопольне становище на ринку крупних перевізників, що у свою чергу робиться 3 потурання конкурсних комітетів. Комісії при виконкомах повинні перевіряти обгрунтованість тарифів, які пропонує перевізник та визначати вартість проїзду для пасажирів. На практиці така перевірка мінімальна та затверджуються тарифи, що запропоновані перевізником, особливо якщо це монополіст.

Не дотримуються графіки руху, які практично завжди не відповідають паспорту маршрута, $є$ проблеми з обладнанням зупинок міського транспорту і т.п.

Таким чином, 3 огляду на реальну ситуацію, що склалась у сфері пасажирських перевезень, Концепція повинна певним чином змінити тяжку ситуацію та включати в себе напрямки для усунення зазначених недоліків.

Однак, зробити це без зміни відповідної нормативно-правової бази вкрай складно.

Закон "Про автомобільний транспорт" https://zakon.rada.gov.ua/laws/show/2344-14 містить визначення поняття автобусного маршруту. Це - илях проходження автобуса міжк початковим та кінцевим пунктами з визначеними місцями на дорозі для посадки (висадки) naсажсирів. Маршрути, за принципом території, згідно тому ж закону, можуть бути: міськими (не виходять за межі населеного пункту), приміськими (об'єднують населені пункти, протяжність не більше 50 км), міжміськими (об'єднують населені пункти, протяжність більше 50 км), міжнародними (перетинають кордон України). За принципом призначення маршрути бувають: загального користування (на яких здійснюються регулярні пасажирські перевезення), спеціальних перевезень (регулярні спеціальні пасажирські перевезення), нерегулярних перевезень (нерегулярні пасажирські перевезення). Присутнє також законодавчо визначене поняття “розклад руху”. Це - сукупність графіків руху автобусів по маршруту.

В нашій Концепції маршрут визначений як сукупність набору зупинок та набору графіків ̈̈x проходження. Це визначення уявляється прийнятним, бо не суперечить вищенаведеному та акцентує увагу на технічному боці питання.

Згідно Концепції один і той же маршрут може мати різні набори графіків руху (“час пік” та “вечірній”) та зупинок, які обслуговуються різними перевізниками, але слід звернути увагу, що згідно з Порядком об'єктом конкурсу може бути сукупність рейсів міського або приміського автобусного сполучення за умови, щц кількість таких рейсів на об'єкті складає не менще 50 за ден b. Таким чином, при запровадженні Концепції потрібно мати на увазі цей момент.

Стаття 44 Закону "Про автомобільний транспорт" встановлює, що договір з переможцем конкурсу (або дозвіл) органи виконавчої влади або органи місцевого самоврядування укладають (або дають) на строк від 3 до 5 років. I далі: дозвіл органів виконавчої влади та органів місцевого самоврядування пасажирському перевізнику на обслуговування автобусних маршрутів надається на строк до 5-ти років. Таким чином, якщо мова йде про конкурс, строк 3-5 років.

Такий самий строк дії укладених договорів та дозволів, що видаються, передбачений пунктом 53 Порядку.

Таким чином, цей строк не може бути змінений без внесення змін в законодавство.

$\mathrm{У}$ той же час очевидно, що саме це положення є перепоною для виникнення здорової конкуренції перевізників та $є$ основою для корупційних схем.

Поняття екіпажу в законодавстві відсутнє. В Концепції передбачено, що перевізником визнається екіпажс одиночного транспортного засобу-перевізника, а згідно Порядку перевізником $є$ транспортна компанія, яка бере участь у конкурсі. Необхідно передбачити в Порядку юридичну можливість оформлення екіпажу в якості окремого учасника конкурсу (фізична особа-підприємець).

Згідно Концепції мова йде про компанії, які залучені за аутсорсингом для медичного та технічного обслуговування. Згідно Порядку, додаткові бали нараховуються за наявності відповідних працівників у самій компанії (не менше 3-х осіб для контролю за технічним станом та не менше 2-х для контролю за станом здоров'я водіїв). Таким чином, допускається їх відсутність у самій компанії та укладення відповідних договорів 3 іншими суб'єктами. Відповідальність за таке забезпечення своєї діяльності повинна нести компанія-перевізник.

Однак, необхідно ввести поняття “організатора перевезень”. В цьому сенсі такого поняття вітчизняне законодавство не містить. За змістом визначення, таким організатором може виступати 
спеціалізований відділ виконавчого комітету (міські перевезення) або держадміністрації (міжміські або приміські перевезення), а також спеціально залучене ним підприємство. Таким підприємством, згідно Порядку, може бути "робочій орган”, який сам визначається на конкурсних засадах та його діяльність полягає в проведенні конкурсу на пасажирські перевезення. 3 ним організатором укладається договір на термін, не більше 3-х років. Уявляється, що законодавство допускає участь такої компанії за договором з місцевими органами влади.

У той же час п. 56 Порядку вказує, що контроль за виконанням умов договору (дозволу) здійснює організатор (виконком, держадміністрація) та інші органи виконавчої влади згідно з компетенцісю, при наявності відповідного звернення або доручення організатора. Тобто, залучена компанія може здійснювати роботу по створенню рейтингів і т.п., однак, контроль залишається прерогативою органів місцевого самоврядування (виконавчої влади).

Наша Концепція передбачає створення рейтингів для перевізників, з якими укладений договір і це повністю узгоджується 3 пунктом 40 Порядку. Передбачено враховувати якість роботи автомобільного перевізника, з яким раніше вже укладався договір (давався дозвіл). Таким чином, згідно з законодавством, це може бути використано при проведенні наступного конкурсу після закінчення 3-5-річного періоду.

Крім того, згідно п.П.3 п.55 Порядку, якщо рейтингові умови будуть включені в договір, укладений 3 переможцем конкурсу, органи влади (самоврядування) можуть достроково розірвати договір з перевізником на підставі порушення ним умов договору (дозволу) за умови зниження сумарного рейтингу нижче, обумовлених умовами конкурсу значень.

Таким чином, встановлення рейтингів уявляється корисним інструментом регулювання якості перевезень, але знову ж таки, якщо виключити вплив корупційної складової цих відносин. У зв'язку з цим корисно, щоб така діяльність проводилась незалежною компанією.

Щомісячна/щоквартальна організація конкурсу у пропонованій Концепції суперечить Порядку на підставі зауважень про строки, що були наведені вище, та може розглядатись лише при внесенні відповідних змін у нормативно-правову базу.

Ми пропонуємо зробити організацію проведення конкурсу на умовах аукціону, але це суперечить існуючому Порядку. Показники, за якими оцінюється кожен перевізник, чітко визначені та не можуть включати інші фактори (п. 40 Порядку). Це 14 пунктів різнобічної характеристики можливостей перевізника. Таким чином, система рейтингового оцінювання Концепції повинна чітко виходити $з$ цього переліку. У той же час, можливе більш широке тлумачення кожного пункту (розбивка його на ряд рейтингоутворюючих показників), що не суперечить законодавству.

На сьогодні підставою для визначення переможця конкурсу є сумарна кількість балів (п.42 Порядку), а не сума, яку перевізник згоден заплатити за маршрут. Втім ми пропонуємо змінити цю норму та обумовити проведення електронних онлайн-торгів. Таким чином, прозорість процесу необхідно забезпечити іншими доступними засобами. Наприклад, розміщення відповідної таблиці рейтингів на сайті міської ради.

Рейтинг маршруту та рейтинги екіпажів можуть також бути покладені в основу додаткових умов конкурсу.

У той же час, вищеописані 14 пунктів Порядку повинні бути присутні вже на етапі оцінки можливостей перевізника, згідно нашої Концепції - при визначенні початкового рейтингу перевізника. Однак, вони не повинні використовуватись як підстава для допуску до конкурсу. В іншому випадку, це обмежує можливості окремих екіпажів та непрямим чином сприяє монополізації ринку пасажирських перевезень у місті.

За Концепцією маршрут надається містом у користування підприємству на праві оренди або іншого платного користування, а організатором конкурсу (а таким чином і відповідальним органом) на міському маршруті є виконавчий орган сільськой, міської ради, на міжміському та приміському маршрутах - обласні держсадміністрації.

Оплата перевізником можливості роботи на маршруті законодавством не передбачена, однак, безпосередньо такий порядок не заборонений. У той же час отримання плати за використання маршруту органами влади або самоврядування $є$ комерційною діяльністю, таким чином, це не може бути представлено як продаж маршруту. Ст. 31 Закону "Про автомобільний транспорт" регулює відносини між перевізником та органами влади чи самоврядування. Згідно з законом орган влади чи самоврядування встановлює в договорі умови організації перевезень, показники якості транспортного обслуговування, термін роботи автомобільного перевізника, 
зобов'язання влади у відношенні обладнання маршруту, підтримки проїзної частини в належному стані, регулювання тарифів і т. п. Уявляється, що при наявності в договорі відповідних пунктів, перевізник може фінансувати покращення інфраструктури на маршруті, встановлення автобусних зупинок і т. п. Для того, щоб забезпечити виконання цих взаємних обов'язків перевізника і влади, створюється комунальне підприємство. В Концепції ми передбачаємо створення Фонду, який покликаний акумулювати кошти, що збираються 3 перевізників на вказані у законі цілі. Саме цими засобами здійснює розпорядження новостворене комунальне підприємство.

Висновки. Таким чином, для ефективного впровадження Концепції в окремому місті необхідно розробити та прийняти відповідні локальні акти: відносно проведення конкурсу, що передбачатимуть ряд основних і додаткових умов; розробити i затвердити систему рейтингового оцінювання перевізника на основі 14 пунктів Порядку; розробити новий шаблон договору 3 перевізником на оренду маршрутів; створити (заключити 3 нею договір) моніторингову компанію, яка буде займатись рейтинговим оцінюванням перевізників.

Окремо необхідно внести до Кабінету Міністрів України пропозиції для внесення змін в Порядок з метою вдосконалення нормативно-правового регулювання цієї сфери.

Пропонованій нами Концепції суперечать наступні пункти (підпункти, абзаци) Постанови КМУ від 03.12.2008 № 1081 "Про затвердження Порядку проведення конкурсу з перевезення пасажирів на автобусному маршруті загального користування": п.12 пп.4, п.22, п.24, п.42, п.46, п.53 (абз. 5, 6, 8), п.55 пп.2, п.58.

Однак наша транспортна Концепція цілком узгоджується з Наказами Міністерства інфраструктури України (Міністерства транспорту та зв'язку України), а саме:

1) Наказом Мінінфраструктури від15.07.2013 № 480 "Про затвердження Порядку організації перевезень пасажирів та багажу автомобільним транспортом";

2) Наказом Мінтранспорту від 07.06.2010 № 340 "Про затвердження Положення про робочий час і час відпочинку водіїв колісних транспортних засобів";

3) Наказом Мінінфраструктури від 20.05.2013 № 305 "Про затвердження Порядку формування, затвердження та ведення реєстру міжнародних, міжміських та приміських автобусних маршрутів загального користування".

У цілому нами пропонується: 1) платність використання інфраструктури міста для перевізників, визначення параметрів та умов, які місто повинне надати за ці кошти; 2) індивідуалізація бізнесу перевезень, перехід від найманої праці до індивідуального підприємництва; 3) організація маршрутів і графіків руху за заявками перевізників; 4) рейтингування перевізників за відкритими параметрами, стартовий та динамічний рейтинги; 5) страхування відповідальності перевізника перед пасажирами за виконання умов договору на здійснення перевезень, відповідальності власника транспортного засобу перед перевізником за технічну справність транспортних засобів, відповідальності перевізника перед власником (розпорядником) транспортного засобу за дотримання умов експлуатації транспортного засобу; 6) мотивування перевізників на самоконтроль 3 використанням прогресивних технічних засобів; 7) мотивування перевізників на надання місту додаткових послуг (наприклад, контроль стану проїжджої частини, мобільне відеоспостереження для охоронних структур і т.п.).

\section{ЛIТЕРАТУРА}

1. Закон України Про автомобільний транспорт. Офіційний сайт ВРУ. Розділ: Законодавство. Електронний ресурс. Режим доступу до джерела: https://zakon.rada.gov.ua/laws/show/2344-14.

2. Порядок проведення конкурсу з перевезення пасажирів на автобусному маршруті загального користування, затверджений Постановою Кабінету Міністрів України № 1081. Офіційний сайт ВРУ . Розділ: Законодавство. Електронний ресурс. Режим доступу до джерела: https://zakon.rada.gov.ua/laws/show/1081-2008-\%D0\%BF .

3. Зак Ю.А. Прикладные задачи теории расписаний и маршрутизации перевозок. Издательство: URSS. 2016, - $394 \mathrm{c}$.

4. Марунич В.С., Шморгун Л.Г. та ін. Організація та управління пасажирськими перевезеннями: підручник/ за ред. доц. В.С. Марунич, проф. Л.Г. Шморгуна - К.: Міленіум, 2017. - 528 с. 